\title{
Antropologia Urbana: \\ desafios e perspectivas
}

\section{José Cuilherme Cantor Magnani}

- Universidade de São Paulo / São Paulo, SP, Brasil

\.jmagnani@usp.br

\section{RESUMO}

Este artigo tem como ponto de partida duas questões. Em primeiro lugar, pode a Antropologia, com os conceitos e métodos de análise forjados ao longo de pesquisas em sociedades de pequena escala, lidar com a heterogeneidade dos atuais aglomerados urbanos, em toda sua diversidade e extensão? E, em segundo lugar, não seria justamente tal legado o que dá ao seu olhar, de perto e de dentro, determinada acuidade, lá onde uma visão apenas de fora e de longe passaria ao largo? O texto começa passando em revista diferentes enfoques diante da cidade e as formas como foi constituída enquanto objeto de análise; em seguida é apresentado o ponto de vista da Antropologia para, finalmente, entrar no tema propriamente dito do artigo: as condições de exercício da etnografia, seu método diferencial, no contexto urbano contemporâneo.
PALAVRas-chave

Antropologia Urbana, etnografia, metodologia, cidades contemporâneas, Circuito sateré na Amazônia. 
Este artigo tem como ponto de partida duas questões. Em primeiro lugar, pode a Antropologia, com os conceitos e métodos de análise forjados ao longo de pesquisas em sociedades de pequena escala - cuja forma de assentamento não, era, precisamente, a cidade - lidar com a heterogeneidade dos atuais aglomerados urbanos, em toda sua diversidade e extensão? Em segundo-e esse é, propriamente, o desafio de fundo - não seria justamente tal legado o que dá a seu olhar, de perto e de dentro, determinada acuidade, lá onde uma visão estritamente de fora e de longe passaria ao largo? A hipótese que se segue pode, assim, ser formulada: a Antropologia, ao acionar-com os necessários ajustes - esse legado e seu modo de operar, a etnografia, oferece um diferencial frente às demais ciências sociais para o entendimento do fenômeno urbano. Para tanto, começarei passando em revista diferentes enfoques diante da cidade e as formas como foi constituída enquanto objeto de análise; em seguida, apresentarei o ponto de vista da Antropologia para, finalmente, entrar no tema propriamente dito deste artigo: as condições de exercício de seu método, a etnografia, no contexto urbano contemporâneo.

\section{A CIDADE NAS CIÊNCIAS HUMANAS}

Desde as primeiras evidências de sua presença em sítios arqueológicos, datadas em torno de cinco mil anos atrás na Mesopotâmia, no vale do Indo, na região andina, entre outros, assentamentos urbanos têm sido objeto de estudo por parte de diferentes disciplinas tais como a História, destacando-se os clássicos Fustel de Coulanges, A cidade antiga (1864); Fernand Braudel, O Mediterrâneo e o Mundo Mediterrânico (1949); Lewis Mumford, A cidade na história (1961); na Arquitetura e Urbanismo, Paolo Sica com La imagen de la ciudad (1970); Norbert Schoenauer, 6.000 Anos de Hábitat (1981) e Leonardo Benévolo, História da cidade (1975); na Ceografia, Harold Mayer e Clyde Kohne, Readings in Urban Ceography (1959) e David Harvey, Condição pós-moderna (1989); na Arqueologia, André Leroi-Courhan, O gesto e a palavra (1964 e 1965) - para citar apenas alguns autores que compulsei, entre outros.

Mais especificamente na Sociologia, e tomando como referência os trabaIhos pioneiros de Émile Durkheim, Ferdinand Tönnies, Georg Simmel e Max Weber, é recorrente o uso do termo "comunidade" ou algum equivalente, sempre em oposição ao de "sociedade". Essa relação contrastiva ficou consagrada a partir da obra de Tönnies (1963), mas se pode reconhecê-la na terminologia durkheimiana, "solidariedade mecânica" versus "solidariedade orgânica" (1973), mutatis mutandis, aponta para a mesma questão. Weber (1999) utiliza o termo comunidade para nomear a cidade do Ocidente que surge por obra da "usurpação" dos moradores do burgo medieval frente ao poder do príncipe ou do bispo e que
1 O artigo aqui apresentado retoma e amplia o esquema da "prova pública oral de erudição", tal como é denominado um dos itens do concurso para obtenção do título de professor titular no Departamento de Antropologia da FFLCH da USP, que prestei em 11 de outubro de 2012 
resultou numa irmandade (communitas), fundamentada por juramento (conjuratio). Segundo Tönnies, a comunidade é marcada por laços de sangue, relações primárias, consenso, rígido controle social; a sociedade, ao contrário, caracteriza-se pela presença de relações secundárias, pela convenção e anonimato. Por meio dessa oposição, o autor descreve a transformação de uma forma tradicional de vida com base numa economia predominantemente de subsistência, "de uma Europa paroquial e agrária para uma sociedade mais cosmopolita e comercial", nos termos de Mellor. A consequente perda de autonomia da economia doméstica para uma produção voltada ao mercado teria significado, para ele, despojar o trabalho de "estilo, dignidade e encanto", ainda conforme essa autora (1984: 290). Tal oposição reaparece em Simmel (1987) quando distingue o tipo metropolitano - espécie de personalidade intelectual, calculista, reservada-do habitante do pequeno povoado, onde a vida descansaria sobre relacionamentos emocionais mais profundos. Como Tönnies, Simmel vai mostrar a transição dos padrões coesivos da comunidade tradicional às formas anônimas e racionais do mundo urbano e industrial.

Frente a essas versões do par opositivo de base, comunidade versus sociedade, qual a posição propriamente da Antropologia? Edmund Leach, em A diversidade da antropologia afirma:
Defendo que os conhecimentos dos antropólogos sociais têm uma qualidade especial, devido à área onde exercitam sua imaginação artística. Essa área éo espaço de alguma pequena comunidade de pessoas que vivem juntas em circuns- tâncias em que a maior parte de suas comunicações diárias depende diretamente da interação. Isto não abrange toda a vida social humana, muito menos abrange toda a história humana. Mas todos os seres humanos gastam grande parte de suas vidas em contextos desta espécie (1989: 50-51).

Esta "preferência" dos antropólogos pela comunidade é também ressaltada por Viveiros de Castro e Gilberto Velho no texto "O conceito de cultura e o estudo de sociedades complexas". Nesse artigo, em que analisam uma variante daquela oposição, não menos conhecida - civilização versus cultura - com base no conceito de Kultur, caro ao Romantismo alemão, reiteram a escolha da Antropologia por esta última:

Na Alemanha, civilização veio indicar as realizações materiais de um povo; cultura, por outro lado, referia-se aos aspectos espirituais de uma comunidade. Enquanto a primeira noção traz em si-em seu uso francês - a ideia de progresso, a outra voltava-se para a tradição; aquela inseria-se no expansionismo colonial, esta marcava a singularidade de cada povo. Ecom efeito, a noção de Civilização 
permanece tingida pelo sentimento de uma especificidade do Ocidente como um todo, de uma autoconsciência satisfeita; a cultura, por sua vez, foi assumida pela Antropologia, discurso ocidental sobre a alteridade. (...) se o conceito de cultura veio a predominar sobre civilização é porque originalmente esse se adequava melhor à proposta da Antropologia (Viveiros de Castro e Velho, 1978: 5).

Assim, "civilização" é associada a progresso, urbanização e a valores ocidentais, enquanto "cultura" é identificada com Volksgeist, voltada para a tradição-o que só reforça, com outros termos, aquele mesmo Grande Divisor. Apesar de a cidade não constituir propriamente um objeto de estudo privilegiado no campo tradicional da Antropologia, posto que é a partir de outras formas de assentamento - o acampamento, a aldeia - que a disciplina vai recortar preferencialmente seus temas de estudo, dois centros universitários voltados para a questão da urbanização, em contextos diferentes, destacam-se: a Escola Sociológica de Chicago, já na década de 1920, e a Escola de Manchester, nos anos 1950.

No primeiro caso, o interesse por questões urbanas surgiu em razão dos problemas advindos da rápida urbanização dessa cidade do centro-norte dos Estados Unidos e, mais especificamente, dos processos migratórios que para ela convergiam: o referencial interpretativo foi a Ecologia Humana e a preocupação inicial era com as "patologias sociais", resultantes justamente das dificuldades e desafios para a inserção das levas de novos habitantes, principalmente do leste europeu, no novo e desconhecido meio. Apesar da denominação "sociológica" do departamento em que esses estudos eram realizados, na Universidade de Chicago, Ulf Hannerz (1986) se refere a alguns dos seus pesquisadores como os "etnógrafos de Chicago", para ressaltar o caráter antropológico dos métodos de trabalho por eles empregados.

Já para a Escola de Manchester, outras foram as transformações sociais que constituíram os temas de pesquisa. Com origem no Instituto Rhodes-Livingstone, na antiga Rodésia do Norte (hoje Zâmbia), o contexto histórico foi a descolonização no continente africano e, mais especificamente, o processo de "destribalização" na África Central: o objeto deslocou-se dos sistemas tradicionais para a emergência de novas nações na era pós-colonial. As mudanças sociais daí decorrentes permearam as preocupações de um grupo de antropólogos de origem sul-africana, os quais, sob a liderança de Max Gluckman, debruçaram-se sobre problemas decorrentes das migrações para as cidades, a habitação, o trabalho assalariado etc. Contribuições dessa escola foram, entre outras, o estudo de redes sociais e a chamada "análise situacional".

Destas duas, foi a Escola de Chicago a que teve influência direta nos estudos urbanos do Brasil, principalmente na Escola Livre de Sociologia e Política, 
fundada em São Paulo em 1933. Tiveram aí destaque os "estudos de comunidade" (Emilio Willems, 1947; Lucila Hermann, 1948; Donald Pierson, 1951; Emílio Willems e Gioconda Mussolini, 1952; Charles Wagley, 1953; Oracy Nogueira, 1962; Antonio Candido, 1964; entre outros), cujos objetos de estudo, contudo, eram vilas e pequenas cidades interioranas e não uma metrópole como Chicago. Foi só mesmo a partir do final dos anos 1970 e começo dos 80 que se inicia uma Antropologia Urbana na então Faculdade de Filosofia Ciências e Letras da usp, voltada para o fenômeno urbano numa cidade de grande porte. Diferenciando-se tanto dos estudos de comunidade como das análises de cunho mais sociológico, as pesquisas pioneiras de Ruth Cardoso e Eunice Ribeiro Durham e as de seus primeiros orientandos marcaram época - não é o caso, porém, de desenvolver aqui este tema, já tratado em trabalho anterior (Magnani, 2012).

\section{A ANTROPOLOGIA E A CIDADE}

Se a cidade não constituiu, nos inícios da disciplina, um objeto de especial interesse para uma análise continuada com base em pesquisas cumulativas-como aconteceu em outros campos da Antropologia-, a crescente predominância da urbanização ${ }^{2}$ e até mesmo a própria fragilização e risco de desaparecimento das sociedades autóctones, conforme alertava Lévi-Strauss (1962), fizeram dela um tema que, finalmente, chegou aos antropólogos. Por falar nesse autor, cabe introduzir aqui a (talvez longa) referência a uma reflexão sua, pouco conhecida, sobre cidade, mas que certamente fornece um bom elemento para a continuidade do argumento que se seguirá. ${ }^{3}$

\subsection{A JORNADA DE LÉVI-STRAUSS}

Em novembro de 1935, deixando para trás as "etnografias de domingo" pelos arredores da cidade de São Paulo onde, nos fins de semana, juntamente com sua então mulher, Dina, registrava festas e folguedos populares, Lévi-Strauss embrenha-se pelo sertão em busca daqueles grupos que, como era de praxe, constituíam o verdadeiro interesse dos antropólogos: populações indígenas.

Em sua jornada, porém, pelo interior paulista, passando por cidades do Norte do Paraná recém-implantadas ao longo de um tronco rodoferroviário, deparou-se com um fenômeno inusitado - núcleos urbanos, de início constituídos por umas poucas casas de troncos falquejados, seguindo técnicas construtivas de imigrantes europeus. Não se tratava, contudo, de uma ocupação desordenada, pois apresentava regularidade, era possível distinguir ali alguns princípios simples, geométricos. "Que misteriosos fatores", perguntava-se Lévi-Strauss (1996:114), seriam responsáveis por aqueles quadriláteros onde
2 Até meados do século XIX, a população urbana mundial não passava de $7.1 \%$

3 Em novembro de 1999, o Departamento de Antropologia da USP organizou um seminário em homenagem a Claude Lévi-Strauss por ocasião de seu $90^{\circ}$ aniversário. Os papers apresentados sobre temas inspirados em sua obra como o parentesco, a mitologia e o método estrutural foram posteriormente reunidos numa edição especial da Revista de Antropologia (42/1-2). Participei da iniciativa como organizador desse número e com o artigo "As cidades de Tristes Trópicos" (Magnani, 1999), em que retomava aspectos pouco lembrados de sua expedição-as impressões causadas pelo processo de urbanização do interior paulista, pelas cidades planejadas do norte do Paraná, pela construção de Goiânia e a comparação com cidades da Îndia e Paquistão. O que segue se remete a algumas dessas reflexões, pois, surpreendentemente atuais, fornecem pistas para avançar na reflexão sobre a cidade em uma perspectiva mais ampliada. 
as ruas eram todas iguais, em ângulo reto? Não escapava à sua observação o fato de que algumas eram centrais e outras periféricas; ora perpendiculares à linha ferroviária ou à estrada, ora paralelas. Por sobre a grade das combinações possíveis distribuíam-se as conhecidas funções urbanas do comércio, dos negócios, da moradia e dos serviços públicos.

Algumas se situavam preferencialmente no sentido do tráfego, enquanto outras procuravam as transversais. Além disso, outro "misterioso" elemento distinguia linhas de ordem e desordem, regendo a distribuição da carência ou abundância: o alinhamento na direção leste/oeste. "Há muito deixamos de adorar o sol", registra ele, mas a persistência em seguir sua trajetória ainda se reveste de atualidade. E prossegue:

(...) a vida urbana apresenta um estranho contraste. Embora represente a forma mais complexa e requintada da civilização, em virtude da concentração humana excepcional que realiza num espaço reduzido e da duração do seu ciclo, precipita no seu cadinho atitudes inconscientes, cada uma delas infinitesimal, mas que, devido ao número de indivíduos que as manifestam do mesmo modo e em grau idêntico, se tornam capazes de engendrar grandes efeitos (Lévi-Strauss, 1996: 116).

Eis, em concisa e elegante enunciação, uma espécie de fórmula de cidade. Explicações que à primeira vista poderiam ser vistas como superstições aqueles "misteriosos elementos" - muitos deles são o resultado de uma forma de pensar que Lévi-Strauss irá desenvolver em O pensamento selvagem (1976), principalmente com a ideia de "ciência do concreto": o espaço possui seus próprios valores, assim como os sons e os perfumes têm cores e os sentimentos, um peso.

Portanto, não é de modo metafórico que é correto comparar-como se fez com tanta frequência - uma cidade a uma sinfonia ou a um poema; são objetos da mesma natureza. Talvez ainda mais preciosa, a cidade se situa na confluência da natureza e do artifício. Congregação de animais que encerram dentro de seus limites sua história biológica e que ao mesmo tempo a modelam com todas as suas intenções de seres pensantes, por sua gênese e sua forma a cidade depende simultaneamente da procriação biológica, da evolução orgânica e da criação estética. É a um só tempo objeto de natureza e sujeito de cultura; indivíduo e grupo; vivida e sonhada: a coisa humana por excelência (Lévi-Strauss, 1962: 116).

A visita a Goiânia em 1937 e as impressões deixadas pela única edificação que então sobressaía na planície, o grande e (segundo ele) desgracioso hotel, 
fornece-Ihe o gancho para continuar a análise. A bordo de um "tapete voador", expressão que emprega como título do capítulo seguinte em Tristes Trópicos, Lévi-Strauss deixa o planalto central brasileiro em direção à Índia e ao Paquistão. A comparação, agora, será numa perspectiva ampla, entre unidades mais afastadas no espaço e no tempo. A visão das ruínas das antigas cidades de Mohenjo-Daro e Harappa, revelando o plano urbanístico em retícula, evoca similares modernos:

Costamos de imaginar que, ao fim de 4 ou 5 mil anos de história um ciclo se encerrou; que a civilização urbana, industrial, burguesa, inaugurada pelas cidades do Indus, não era tão diferente, em sua inspiração profunda, daquela fadada, após uma longa involução na crisálida europeia, a alcançar a plenitude do outro lado do Atlântico. Quando ainda era jovem, o mais Velho Mundo já esboçava o semblante do Novo (1962: 122).

Marília, Presidente Prudente, Londrina, Arapongas, Goiânia, Calcutá, Mohenjo-Daro... Em que medida e por quais razões realidades tão distantes no tempo, tão díspares quanto aos processos de sua formação histórica poderiam ser pensadas como elementos de um mesmo conjunto? Em que aspectos o mundo mais antigo se revela no rosto do novo? O que há em comum entre essas cidades certamente não está no plano do contingente, mas no de uma estrutura de mais longa duração, à qual só se chega pela identificação de uma "forma-cidade" mais perene.

Com base nessas formulações é até tentador agrupar, no mesmo quadro, outras imagens, histórica e espacialmente tão distantes como a aldeia bororo e a estreita relação de sua forma espacial com a organização social; a mandala que prefigura em sofisticado desenho o traçado da cidade indiana e determina sua implantação concreta; o padrão em retícula de Hipódamo de Mileto em cidades gregas, o gesto do centurião romano com sua groma, traçando no solo os cardines e decumani que fundam mais uma urbs, após a devida consulta aos augures; e, finalmente, até mesmo o urbanista moderno inclinado sobre seu projeto na prancheta ou diante de um programa na tela do computador. Essas imagens pressupõem pares como prefiguração/implantação, modelo/ realização, projeto/obra que, certamente, não poderiam ser dispostos numa sequência sintagmático-evolutiva-do mais simples para o mais complexo-, pois o que realmente lhes dá sentido comum é o pertencimento a um mesmo conjunto sincrônico-paradigmático.

Levando em conta tais agrupamentos, até se pode constatar neles uma certa homologia de escala, mas o que diria Lévi-Strauss diante do espetáculo de ajuntamentos humanos da ordem de dezenas de milhões de pessoas, como 
é o caso de alguns dos maiores centros urbanos contemporâneos? A julgar pelas conclusões de algumas análises sobre os rumos e consequências do processo de urbanização atualmente em curso, parece improvável que se pudesse continuar afirmando que a cidade "é a coisa humana por excelência". Mas seria possível, mesmo assim, identificar nelas uma estrutura comum? Em termos... E é o próprio quem faz a ressalva:

Nunca me ocorreu a ideia - que me parece extravagante - de que tudo na vida social esteja sujeito à análise estrutural (...) aqui e a li formam-se algumas ilhotas de organização. Minha história pessoal, minhas opções científicas fizeram com que me interessasse mais por elas do que pelo resto (Lévi-Strauss e Eribon, 1990: 133).

Sua escolha pelos domínios do parentesco e do mito, coetâneos à própria humanidade, deixa clara ao menos duas condições para a viabilidade desse tipo de análise: a dimensão do corpus e a universalidade da ocorrência. Com relação ao fenômeno urbano, contudo, há que reconhecer que nem sempre os homens viveram em cidades e que nem todos moram nelas; só muito recentemente, aliás, a urbanização tornou-se uma tendência mais geral, de forma que princípios porventura responsáveis por sua estruturação no plano da longa duração ainda não teriam tido tempo suficiente para decantar.

Mas... quem sabe? Talvez em determinados períodos históricos algumas cidades pudessem ser vistas como partes de um conjunto e, formando um corpus reconhecido, ser incluídas naquelas “ilhotas”. Em sua clássica análise sobre a emergência da cidade ocidental, na seção "A dominação não legítima - tipologia das cidades" (1999, vol 2: 408 e ss.), Max Weber aponta a usurpação por parte dos moradores do burgo, diante do poder do senhor feudal, como o ato fundador desse núcleo urbano que tem como elementos constitutivos a fortaleza, o mercado e o tribunal. Seu funcionamento, segundo regras acordadas em função das necessidades econômicas, jurídicas e políticas dos burgenses, só foi possível porque este arranjo tinha como pressuposto a dissolução do que ele chamou de laços clânicos - fundados em lealdades de parentesco - garantindo o governo autônomo, uma associação livre, por meio de um juramento, a conjuratio. "O ar da cidade torna livre" era o adágio que justificava o acolhimento dos que se desgarravam dos vínculos senhoriais ou perambulavam à margem deles. As típicas cidades da Alta Idade Média, cuja dinâmica era ditada pelo padrão de crescimento orgânico, tinham em seu centro, delimitado pelas ruas, praças e largos, aqueles equipamentos - ao mesmo tempo símbolos e sede do poder. Como não reconhecer, nesse corpus, a presença de uma estrutura de base? ${ }^{4}$

4 E como não lembrar aqui, muitas de nossas cidades interioranas com seu coreto na praça central, ladeada pela "casa de câmara e cadeia", a prefeitura, a igreja matriz... 


\subsection{A CIDADE CONTEMPORÂNEA}

Talvez lá fosse possível, mas a realidade atual dos processos de urbanização há muito deixaram para trás esse modelo. Aliás, Jürgen Habermas, numa conferência (1992 [1981]) em que discutia a arquitetura no contexto da polêmica modernismo versus pós-modernismo, já alertava para isso: ao contabilizar as frustradas tentativas das propostas típicas da arquitetura moderna - salvar o centro, manter a divisão entre quarteirões residenciais e comerciais, entre áreas verdes e de instalações industriais, organizar o tráfego etc. ${ }^{5}$ - o filósofo se questionava "se o próprio conceito de cidade não está ultrapassado":

As marcas da cidade ocidental, como Max Weber a descreveu, da cidade burguesa na Alta Idade Média europeia, da nobreza urbana na Itália do norte renascentista, da capital dos principados, reformada pelos arquitetos barrocos da casa real, estas marcas históricas confluíram em nossas cabeças até formarem um conceito difuso e multiestratificado. Este pertence ao tipo identificado por Wittgenstein como parte dos hábitos e da auto-compreensão da prática cotidiana: nosso conceito de cidade liga-se a uma forma de vida. Esta, contudo, se transformou a tal ponto que o conceito dela derivado já não logra alcançá-la (1992 [1981]: 123).

O autor prossegue: "Enquanto um mundo abarcável, a cidade pôde ser arquitetonicamente formada e representada para os sentidos", o que quer dizer que as funções sociais da vida urbana - nos seus aspectos econômicos, políticos, culturais, de práticas religiosas, da vida cotidiana no âmbito do morar, da recreação, da festa-podiam ser vivenciadas e percebidas num marco temporal e espacial claramente configurado. Contudo, já "no século XIX ao mais tardar, a cidade torna-se ponto de intersecção de relações funcionais de outra espécie" (grifo meu). As próprias estações ferroviárias, por exemplo, já não permitiam a apreensão do tráfego ao longo de suas linhas, muito diferente da "clareza com que outrora os portões da cidade sugeriam as ligações concretas com as vilas adjacentes e a cidade mais próxima". A vida urbana é cada vez mais mediada por "conexões sistêmicas não configuráveis" e "as aglomerações urbanas emanciparam-se do velho conceito de cidade ao qual, no entanto, se apega nosso coração" (Habermas, 1992 [1981]: 123).

Se tal é o diagnóstico das metrópoles modernas do século XIX, então já da ordem de milhões de habitantes - Paris, cenário para os poemas de Baudelaire e os romances de Eugène Sue e Gustave Flaubert, tinha 2 milhões; a Londres de Charles Dickens, Frederic Engels e Edgar Allan Poe, 2,6 milhões; e mesmo na Berlim de Simmel, a população era de 1,5 milhão-, que dizer do quadro
5 Proposta que remete ao ideário da Carta de Atenas em que Le Corbusier (1989 [1941]) sintetiza os resultados do quarto CIAM (Congresso Internacional de Arquitetura Moderna) (1933), considerado uma espécie de manifesto do chamado urbanismo racionalista. 
atual em que, para ser ter uma ideia, já em 1975 três cidades - Tóquio, Nova York e a Cidade do México - tinham mais de 10 milhões de habitantes? Em 2005, já eram 20!

Para levar adiante essa polêmica, cabe observar que urbanistas contemporâneos tentam, mesmo assim, detectar padrões de urbanização nesses imensos aglomerados, com base em fatores e variáveis macro estruturais. Olivier Mongin (2005), por exemplo, retoma uma discussão iniciada por Saskia Sassen (1991) sobre "cidade global" e estabelece novas distinções: sua tipologia, no contexto do que denomina a terceira fase da globalização - caracterizada pela prevalência dos fluxos sobre os lugares-, é mais abrangente. Desta forma, distingue três momentos ou fases desse processo: a primeira, em fins da Idade Média e do Renascimento, com a emergência das "economias-mundo capitalistas"; a segunda, da sociedade que emerge da Revolução Industrial; e a terceira, a fase da passagem das "economias-mundo" para uma "única economia-mundo" a partir dos anos 1960, com base em novas tecnologias e na perda de importância do Estado enquanto principal motor da política industrial.

A condição urbana generalizada, que empurra seus limites em virtude da predominância dos fluxos sobre os lugares, caracteriza-se, segundo este autor, por um tipo de crescimento que leva tanto ao fenômeno das "megacidades" como também ao das cidades com acesso privilegiado ao mundo ilimitado do virtual - estas últimas seriam as "cidades globais", na denominação de Sassen. A "megacidade", ou "cidade-mundo" - cuja maior ocorrência se dá na Ásia, África e América Latina -, caracteriza-se pela extensão espacial e demográfica, enquanto a cidade global é a cidade conectada aos fluxos globalizados. Entre ambas, situa-se a "metrópole", marcada pela presença de uma pluralidade de polos urbanos designados como inner cities, suburban corridors, gated communities e outros neologismos, cujos exemplos são encontrados na África do Sul (Pretoria, Joanesburgo) e nos EUA (San Francisco, Indianápolis), entre outros. Lagos, México e São Paulo pertenceriam ao primeiro tipo, "megacidades", enquanto Londres, Tóquio e Nova York tipificam as "cidades globais", aquelas que, na acepção de Sassen, constituem as novas centralidades da rede econômica globalizada, com um território bem circunscrito e protegido.

A discussão sobre fluxos globais não é estranha à Antropologia. Há autores que enfatizam os efeitos homogeneizadores do sistema mundial sobre culturas locais, creditando tal influência à "grande narrativa da dominação ocidental", conforme a expressão usada por Marshall Sahlins para designar essa leitura (1997: 15). Nesse artigo, “O 'pessimismo sentimental' e a experiência etnográfica”, o autor mostra, porém, com base em etnografias recentes, que não há uma só lógica nem uma única direção no fluxo transnacional por onde transitam pesso- 
as, mercadorias e recursos. Não raras vezes esse intercâmbio termina fortalecendo costumes e instituições tradicionais num dos polos, aquele constituído pela longínqua aldeia de origem, e todo esse processo em suas múltiplas facetas é designado por Sahlins como "indigenização da modernidade".

Mas o propósito aqui não é discutir a ordem internacional e sim delimitar um campo no qual se possam considerar alternativas de análise voltadas para a dinâmica interna da cidade contemporânea. Grande parte das análises, contudo, principalmente quando o foco são as cidades que Mongin classifica como cidades mundo situadas no chamado Terceiro Mundo, produz leituras na chave do caos urbano, da precariedade dos equipamentos, da desigualdade social. Ilustrativo dessa postura foi o ocorrido com o conhecido urbanista catalão, Jordi Borja, em uma de suas visitas a São Paulo. Convidado a participar de um programa de televisão para falar dos problemas das grandes cidades, foi previamente instruído pelo jornalista: "Quero que o senhor diga como a cidade de São Paulo está mal, uma catástrofe, nada funciona etc.; que diga também como, em geral, as cidades vão mal, com problemas de insegurança, contaminação, falta de moradia, proliferação de bairros marginais, pois em todas as cidades há grandes problemas." Prossegue o depoimento: "Respondi-lhe: sim, é verdade, mas interessa-me mais ver que tipo de respostas é possível dar a esses problemas. Então já não Ihe interessou a entrevista e a desmarcou. Já estávamos esperando na porta do estúdio para começar e mesmo assim a desmarcou" (tradução minha, Borja, 1995: 11).

Tomando como referência a capital paulistana, que certamente se encaixaria na classificação de "cidade mundo", com sua imensa periferia, não se pode, contudo, reduzi-la simplesmente a uma cidade que cresceu demais e desordenadamente-daí suas mazelas e distorções. A própria escala - tal como a de outros aglomerados urbanos assemelhados - impõe novos parâmetros na distribuição e na forma de seus espaços públicos, nas suas relações com o espaço privado, no papel dos ambientes coletivos e nas diferentes maneiras por meio das quais os agentes (moradores, visitantes, trabalhadores, funcionários, setores organizados, segmentos excluídos, "desviantes" etc.) usam e se apropriam de cada uma dessas modalidades de relações espaciais.

Para além da nostalgia pela "velha rua moderna" (Berman, 1989:162) ou do "balé das calçadas" (Jane Jacobs, 1992 [1961]: 50) - posturas críticas ao ideário já ultrapassado do projeto modernista da Carta de Atenas (Le Corbusier, 1989 [1941]) - certamente haveria que se perguntar se o exercício da cidadania, das práticas urbanas e dos rituais da vida pública não teriam, no contexto dessa e outras grandes cidades contemporâneas, outros espaços e estratégias: para tanto, é necessário procurá-los com uma estratégia adequada. 


\section{A PROPOSTA DA ANTROPOLOGIA}

É o que se propõe com a Antropologia, por meio do método etnográfico. As grandes cidades certamente são importantes para análise e reflexão não apenas porque integram o chamado sistema mundial e são decisivas no fluxo globalizado e na destinação dos capitais e mão de obra, mas também porque concentram serviços, oferecem oportunidades de trabalho, produzem comportamentos, determinam e/ou acolhem estilos de vida - e não apenas aqueles compatíveis com o circuito dos usuários abonados, do grande capital, frequentadores da rede hoteleira, de gastronomia e de lazer que seguem padrões internacionais, tido como marca da "cidade global" de Sassen e Mongin.

A presença de imigrantes, visitantes, moradores temporários, refugiados e de minorias; de segmentos diversificados com relação a orientação sexual, necessidades especiais, identificação étnica ou regional, preferências culturais e crenças; de grupos articulados em torno de opções políticas e estratégias de ação contestatórias ou propositivas e de segmentos marcados pela exclusão - toda essa diversidade leva a pensar não na fragmentação de um multiculturalismo difuso, mas na possibilidade de sistemas de trocas em outra escala, com parceiros até então impensáveis, ensejando arranjos, iniciativas, experiências e conflitos de diferentes matizes.

É evidente que não há como negar todos aqueles problemas apontados nos diagnósticos com base nos grandes números, comprovados também pela própria experiência do dia-a-dia dessas grandes cidades; nem, evidentemente, as injunções dos interesses das corporações transnacionais e das elites locais nos sistemas decisórios sobre o ordenamento urbano e sua influência na deterioração da qualidade de vida de grande parte da população.

Mas a pergunta que ainda paira é: isso é tudo? Este cenário esgota o leque das experiências urbanas? Não seria possível chegar a outras conclusões, desvelar outros planos mudando este foco de análise, de longe e de fora, com base em outros métodos e instrumentos de pesquisa como os da Antropologia, por exemplo? É aqui que entra a perspectiva de perto e de dentro, como proposta para dar início à apreensão dos padrões de comportamento - não de indivíduos atomizados, mas dos múltiplos, variados e heterogêneos conjuntos de atores sociais cuja vida cotidiana transcorre, por meio dos seus criativos arranjos, na paisagem da cidade e em diálogo com seus equipamentos.

\subsection{A ETNOGRAFIA}

Assim, se a Antropologia, com base em tudo que foi dito, não pretende abrir mão de refletir sobre essas novas formas de ajuntamento humano com suas 
dinâmicas, características e problemas e específicos, a partir de uma perspectiva etnográfica, a primeira tarefa que se coloca é definir o ponto de partida: a própria cidade enquanto unidade, ou as múltiplas práticas que nelas se desenvolvem? Tendo em vista justamente a complexidade, dimensão e heterogeneidade das cidades contemporâneas, parece impraticável tomá-las como um recorte pronto e dado para aplicação do método etnográfico. Não é demais lembrar que em Na Metrópole já estava um alerta:

"Da porta da minha barraca", escreveu Evans-Pritchard nas primeiras páginas de sua clássica etnografia, "podia ver o que acontecia no acampamento ou aldeia e todo o tempo era gasto na companhia dos Nuer". Se esta passagem de Os Nuer: uma descrição do modo de subsistência e das instituições políticas de um povo nilota (1978 [1940]: 20) constitui a imagem canônica da pesquisa de campo, nada mais distante, então, das condições de trabalho de um antropólogo às voltas com questões e problemas característicos das modernas sociedades urbano-industriais, cujo campo é a cidade: da janela de seu apartamento não tem diante de si o espetáculo da vida social em sua totalidade e mesmo que conviva mais intensamente com o grupo que está estudando, nem sempre gasta todo o tempo em sua companhia (Magnani e Torres, 1996: 19-20).

Continuava o alerta:

Cabem, por conseguinte, as perguntas: podem os antropólogos, com os conceitos e instrumentos de pesquisa forjados no estudo dos então chamados povos "primitivos"-observação participante, análise qualitativa, foco de análise dirigido para recortes empíricos bem limitados e definidos - dar conta da complexidade que caracteriza as sociedades contemporâneas? Como estabelecer as mediações necessárias entre o trabal ho de campo-particularizado, minucioso, atento para cada detalhe - e instâncias interpretativas mais amplas? Poderão superar, os antropólogos, a tentação do "padrão aldeia" e assim articular a singularidade de seu objeto com outras variáveis da vida urbana, principalmente nas grandes e superpovoadas metrópoles? (Magnani e Torres, 1996: 20)

Trata-se, a bem da verdade, de uma contraposição um tanto retórica, pois nem mesmo nas atuais pesquisas de etnologia com populações indígenas o foco $\mathrm{da}$ análise se restringe a recortes com fronteiras bem definidas e fechadas. $\mathrm{O}$ desafio, no entanto, é real, conforme já anunciado no inicio deste texto: de um lado está a cidade contemporânea que não configura uma unidade operacional, claramente delimitada, nem mesmo para a governança - haja vista as dificulda- 
des para estabelecer planos diretores abrangentes -e, de outro, o risco de ceder à fragmentação e cair na "tentação da aldeia".

Entretanto, se não há uma ordem, isso não quer dizer que não haja nenhuma. Se essas cidades já não apresentam um ponto de referência nítido nem contornos definidos capazes de identificar uma única centralidade (Frúgoli, 2000) e projetar uma imagem de totalidade, é preciso começar por estabelecer mediações entre o nível das experiências dos atores e o de processos mais abrangentes e assim reconstituir unidades de análise em busca de regularidades, sob pena de se embarcar (e se perder) na multiplicidade dos arranjos particularizados. Daí a necessidade de contar com instrumentos que permitam uma articulação entre tais planos.

Foi esse o propósito do emprego das categorias de pedaço, mancha, trajeto, circuito e pórtico, aplicadas a determinados campos como o lazer, práticas corporais, novas modalidades de religiosidade, formas de sociabilidade - entre outros, nas pesquisas do Núcleo de Antropologia Urbana (NAU). Desta forma, pretende-se recuperar a ideia do "infinitesimal" aduzida por Lévi-Strauss nas referências trazidas anteriormente. Assim - e aqui me permito esta longa transcrição de um trecho do livro Da periferia ao centro: trajetórias de pesquisa em Antropologia Urbana (Magnani, 2012: 292-293):

(...) Quando uma iaô deposita a oferenda para seu orixá em determinada esquina da cidade, tal atitude pode ser creditada a fatores subjetivos, individuais (conveniência pessoal, proximidade, facilidade de locomoção) ou a ditames da nação ou linhagem a que pertence, no quadro mais geral das religiões afro-brasileiras. Contudo, a preferência por determinadas ruas e encruzilhadas, ou, no caso de determinados "despachos", por áreas mais abrangentes como cemitérios ou parques - constituindo, quem sabe, uma mancha-, já levanta pistas para pensar a relação entre uma prática religiosa e significados atribuídos a determinados espaços da cidade.

O mesmo pode ser aplicado a outra manifestação da religiosidade contemporânea: que um ou outro espaço neo-esotérico realize algum tipo de cerimônia para celebrar a auspiciosa ocorrência da Lua Cheia, tal fato pode ser explicado em razão de escolhas doutrinárias ou filosóficas desse centro em particular. Mas quando se descobre que tal forma de celebração ocorre com regularidade e com uma mesma estrutura ao longo de um circuito, independentemente dos (incontáveis) sistemas que servem de base a cada uma das instituições que o integram - de tal forma que, como rito, já virou evento de um verdadeiro calendário-, pode-se supor que se está diante de uma recorrência de outra ordem.

E nem sempre essas regularidades e ordenamentos são agenciados dentro das vias legais. As ordens (e a "ordem") de facções do chamado crime organizado, por exemplo, que das prisões normatizam o cotidiano de certos (ou segmentos 
de) bairros da periferia, produzem efeitos surpreendentes, como mostrou o caso de uma mãe obrigada por elementos do crime organizado a denunciar o filho, acusado de assassinato, para evitar incursão da polícia na área, conforme noticiado pela mídia em 15 de janeiro de 2009. Normas e princípios inspirados no decálogo do PCC (Primeiro Comando da Capital) migram para outras áreas e se combinam com seus códigos de conduta, como os do hip-hop, rap, torcidas organizadas de futebol, pichadores, nas quais o dístico "lealdade, humildade, proceder", por exemplo, é invocado para regular relações entre os membros de algum pedaço, entre estes e os de fora e também com a polícia.

Vez por outra, alguns canais de troca e regras de convivência entre ordenamentos diferentes se chocam. A favela de Paraisópolis, a segunda maior da cidade e que em suas origens abrigou famílias dos trabalhadores que construíram o estádio do Morumbi, faz fronteira-tem seu pórtico-com o bairro desse nome, de classe alta. Domésticas, porteiros, encanadores, vigias e outros profissionais oriundos da favela prestam serviços aos moradores do Morumbi; escolas de alto padrão, além de outras instituições da região, entre as quais o Hospital Albert Einstein, mantêm nela alguns programas sociais, conhecidos como "projetos". Mas é uma favela em que milicianos, traficantes, associações de moradores e policiais mantêm uma instável rede de divisão de poderes e que foi rompida quando alguns dos atores quebraram certas regras. O protesto, permitido e incentivado por uma das facções, saiu do controle e, aí sim, uma operação da ordem oficial fez-se presente, atravessando o pórtico de forma espetacular-com carros blindados, pelotões de choque, tropas de elite-, desorganizando temporariamente o equilíbrio da complexa mancha onde transcorre o cotidiano de 60.000 moradores da favela e as relações de muitos deles com os abonados vizinhos. Os incidentes ocorreram em fevereiro de 2009 e a intervenção das forças policiais foi denominada "Operação Saturação".

Seguindo outras pistas, distante de zonas fortemente marcadas pela ilegalidade, em certos movimentos culturais de periferia são feitos contatos e alianças com jovens de outras regiões, alguns universitários, que descobrem novos trajetos mas devem seguir as regras do pedaço que começam a frequentar. Um exemplo é a Cooperifa e seu sarau literário com sede no bar do Zé Batidão, Jardim São Luís, Zona Sul; cabe registrar que já se formou um circuito de saraus, nos moldes da Cooperifa, em diversos bairros da periferia de São Paulo.

Às vezes, essas alianças são francamente surpreendentes, como as estabelecidas entre os straight edgers e os hare krishnas - em torno, não de convicções religiosas, mas da comida vegana que ambos compartilham... Num bairro popular perto do campus da USP, o Morro do Querosene, com significativa presença de alunos, professores, artistas e artesãos, - o "bumba meu boi" coordenado por Tião Carvalho cumpre seu ciclo anual de morte, ressurreição e batismo. Nesse 
rito, a dinâmica do folguedo maranhense mescla-se com o ritmo da cidade, criando um "sotaque" próprio e estabelecendo um circuito de longo alcance. Com apoio de oncs e instituições voltadas para cultura popular, como Grupo Cupuaçu, Cachuêra, as Caixeiras do Divino da Família Menezes, formado principalmente por idosas tocadoras do instrumento de percussão (as "caixas"), fazem seus trajetos desde São Luís do Maranhão durante as rezas para participar, todo ano, dos festejos deste ciclo da religiosidade tradicional. (... $)^{6}$

E assim sucessivamente com relação, por exemplo, à ocupação de determinados espaços e áreas da cidade para práticas esportivas ou como pontos de consumo cultural, de convivência, de celebrações e de protestos. Estes e muitos outros comportamentos, atitudes e práticas - "infinitesimais”, quando encarados do ponto de vista das motivações de cada grupo participante numa urbe de mais de 12 milhões de habitantes - deixam entrever modelos, sistemas classificatórios e formas de organização mais gerais se descritos e analisados desde a perspectiva de seus princípios estruturantes.

E é justamente isso que as referidas categorias - pedaço, mancha, trajeto, pórtico e circuito-se propõem a fazer: partem da experiência vivida dos atores sociais envolvidos, mas, em vez de ficarem presas a uma descrição particularista e circunscrita a cada caso, apontam para arranjos compartilhados e regularidades. Quem, por exemplo, já estudou terreiros de candomblé, coletivos de jovens, escolas de samba, torcidas organizadas de futebol, o circuito LCBT etc. sabe que nestes e em outros casos análogos há recortes ou unidades cujas fronteiras e graus de pertencimento são vivamente experimentados pelos integrantes do grupo. Tomando como exemplo a categoria de pedaço, é evidente, por parte de seus integrantes, uma percepção imediata, sem nuanças ou ambiguidades, a respeito de quem pertence ou não a ele: trata-se de uma experiência concreta e compartilhada. O etnógrafo, por sua vez, também percebe tal experiência e a descreve, pois essa modalidade particular de encontro, troca e sociabilidade supõe a presença de elementos mínimos estruturantes que a tornam reconhecível em outros contextos.

O mesmo ocorre com as demais categorias: cada uma, à sua maneira, permite identificar um arranjo especial, por parte de seus integrantes e revela um tipo especial de consistência: se no pedaço não há lugar para estranhos, a mancha tem mais amplitude, pois acolhe mesmo quem não se conhece pessoalmente, já que o elemento que une é a identificação por um certo gosto musical, estilo de vida, orientação sexual, religiosa, etc. e tem uma implantação mais estável na paisagem urbana. Já circuito é mais abrangente, pois liga pontos sem necessariamente haver contiguidade espacial, permitindo trocas entre parceiros distantes: transcende fronteiras físicas. ${ }^{7}$ Trajetos levam de um pedaço a outro, ou cortam as manchas, transpondo pórticos. Como se pode ver, trata-se de unidades calcadas

6 Aqui se encerra a citação a Magnani (2012: 292-293).

7 Exemplos concretos, descritos em pesquisas no Núcleo de Antropologia Urbana: os pedaços dos pichadores; a mancha de lazer da Vila Madalena ou a dos gays do Largo do Arouche, o circuito black metal, os trajetos dos skatistas etc. 
em vivências concretas dos atores sociais, mas também são unidades de análise que permitem identificar, descrever, comparar, para além de experiências particularizadas: têm-se como resultado diferentes graus de consistência. ${ }^{8}$

\subsection{UNIDADES DE SENTIDO/UNIDADES DE INTELIGIBILIDADE}

Assim, o conhecimento que resulta desta particular forma de aplicação do método etnográfico tem como pressuposto a ideia de que o objeto de observação e estudo tem duas faces: uma, relacionada com o agente, é a que faz sentido imediato para ele, pois é sua prática; a outra é percebida pelo pesquisador, que reconhece esse sentido e o descreve, nos seus termos. Em trabalhos anteriores (Magnani, 2012, 2014) fiz uma aproximação com a formulação de Marc Augé que, evocando os "lugares de memória" de Pierre Nora (1984), fala em "lugar antropológico": segundo seus termos, seria "simultaneamente princípio de sentido para aqueles que o habitam e princípio de inteligibilidade para quem o observa" (Augé, 1994: 51). Do ponto de vista do agente, trata-se de um "arranjo", resultado de escolhas frente a um repertório de alternativas; o observador reconhece-o, segue-o e, no processo de investigação, refere-o a outros recortes, quando, então, constitui uma "unidade de análise" em outro nível.

Outra referência vai nessa mesma direção: trata-se do "momento etnográfico" de Marilyn Strathern. ${ }^{9}$ Em O efeito etnográfico (2014) - e, mais precisamente, no capitulo 12 que justamente dá o título ao livro-a autora descreve algumas estratégias da inserção etnográfica em campo e sua contrapartida na elaboração posterior. Segundo ela, a tarefa é não apenas compreender os efeitos de certas práticas e artefatos na vida das pessoas, mas recriar esses efeitos no contexto da escrita; a análise já começa em campo, mas a influência dos atores sociais (os "anfitriões" do etnógrafo, na linguagem da autora) continua sobre estes. A divisão entre tais momentos cria dois tipos de relação: a primeira separa, dando a ideia de que uma coisa é a observação e, outra, a análise; mas a segunda relação os junta-e este é o "momento etnográfico":

O momento etnográfico é uma relação, assim como um signo linguístico pode ser pensado como uma relação (ao juntar significante e significado). Poderíamos dizer que o momento etnográfico funciona como exemplo de uma relação que junta o que é entendido (que é analisado no momento da observação) à necessidade de entender (o que é observado no momento de análise). (Strathern, 2014:350)

Portanto, uma unidade consistente em termos da etnografia é aquela que, experimentada e reconhecida pelos atores sociais, é identificada pelo investigador podendo ser trabalhada como categoria de maior alcance. Para os primeiros,
8 “(...) essas categorias não se excluem e são justamente as passagens e articulações entre seus domínios que permitem levar em conta, no recorte da pesquisa, as escalas das cidades e os diferentes planos da análise. Elas constituem uma gramática que permite classificar e descrever a multiplicidade das escolhas e os ritmos da dinâmica urbana não centrados nas escolhas de indivíduos, mas em arranjos mais formais em cujo interior se dão essas escolhas" (Magnani, 2002: 26).

9 Ana Fiori, leitora de Strathern, foi quem sugeriu essa aproximação. 
é o contexto da experiência e, para o segundo, um recurso descritivo, chave de inteligibilidade. Uma vez que não se pode contar com uma unidade dada a priori, postula-se uma a ser construída a partir da experiência dos atores e com a ajuda de hipóteses de trabalho e escolhas teóricas como condição para que se possa dizer algo mais que generalidades a respeito de tal ou qual objeto de estudo.

Assim, aqueles dois planos a que se fez alusão anteriormente, evocando Lévi-Strauss - o infinitesimal versus a forma estrutural; ou, em outra formulação, a cidade em seu conjunto versus cada prática cultural associada a este ou àquele grupo de atores em particular, ou ainda, numa fórmula mais concisa, antropologia da ou na cidade - devem ser considerados como dois polos de uma relação que circunscrevem, determinam e possibilitam a dinâmica estudada. Para captar os vários planos dessa dinâmica, por conseguinte, é preciso situar o foco nem tão de perto que se confunda com a perspectiva particularista de cada usuário, e nem tão de longe a ponto de distinguir um recorte abrangente, mas genérico e sem rendimento explicativo. Em outros termos, nem no nível das grandes estruturas físicas, econômicas, institucionais etc. da cidade, nem no das escolhas individuais: há planos intermediários nos quais se pode distinguir a presença de padrões, de regularidades. Para captá-los é preciso, por conseguinte, modular o olhar. Entre o "de fora e de longe" e o "de perto e de dentro" certamente há nuanças e gradações que permitem variar ângulos e escalas da observação

Postular regularidades ou padrões e não dissonâncias ou desencontros como condição da pesquisa supõe uma contrapartida no plano teórico: ter alguma ideia de totalidade como pressuposto - se é que se pode usar esse termo, em razão das suas conotações estrutural-funcionalistas. ${ }^{10} \mathrm{Em}$ todo caso não se trata, como já foi reiterado, daquela "totalidade" que evoca um todo orgânico, funcional, sem conflitos, e tampouco aquela que coincide, no caso da cidade, com os seus limites político-administrativos. No entanto, renunciar a esses tipos de totalidade não significa embarcar no extremo oposto: um mergulho na fragmentação - pois, como já foi dito, se não se pode delimitar uma única ordem, isso não significa que não haja ordem alguma. A questão da totalidade coloca-se, dessa maneira, em múltiplos planos e escalas, como essa "família de categorias"11 sugere: trata-se de um tipo de consistência que conforma conjuntos em diferentes escalas, com graus sucessivos de abrangência, para além da visão "microscópica" geralmente atribuída à etnografia, na esteira de uma certa leitura de Ceertz (1978). ${ }^{12}$

Vale lembrar, a propósito, uma passagem da "Introdução à obra de Marcel Mauss", onde Lévi-Strauss mostra as implicações do conceito de fato social total para a antropologia e as condições de seu correto entendimento: de um lado, "o social não é real senão integrado em sistema" e, de outro, "é preciso que ele se encarne numa experiência individual" (Lévi-Strauss, 1971: 23). Mais adiante, o an-
10 Não obstante as sucessivas releituras ou revisitas, como as críticas de Marcus (1991) e também as de Clifford (1998) sobre a comunidade "realista", uma certa noção de totalidade como condição da pesquisa antropológica acompanha a disciplina desde as etnografias clássicas.

11 Tal "família de categorias" mantém relações entre seus componentes: pode haver pedaços no interior de uma mancha; os trajetos levam de um pedaço a outro, passando por pórticos; um circuito, constituído por diferentes trajetos, pode abrigar vários pedaços e manchas, e assim por diante.

12 Cabe aqui uma referência à entrevista concedida por Marilyn Strathern a Viveiros de Castro e Carlos Fausto em que expressa, entre outras observações, sua ojeriza a determinadas noções em voga no discurso antropológico: “(...) Comecemos por dizer que há toda uma série de conceitos que não tolero. Isto não significa - para voltarmos à questão da contradição e das estratégias retóricas - que eu não os tenha utilizado alguma vez; mas assim em abstrato, realmente não os posso tolerar. Tudo isso começou lá atrás, com John Barnes; começou com aquela ideia de que se você não tem grupos de descendência nitidamente recortados, então, de alguma forma, você está diante de uma realidade fluida. Havia toda uma linguagem de fluidez e ambiguidade que eu não conseguia aturar, pois me parecia, simplesmente, que o que os etnógrafos estavam fazendo não era descrevendo situações fluidas observáveis - eles estavam, sim, sendo imprecisos e descuidados com sua linguagem. Assim, quando alguém começa a dizer: bem, as coisas são muito mais ambíguas etc., procuro logo saber se ele ou ela realmente quer dizer ambíguo, se ele/a entende 
tropólogo explicita o argumento quando, após enumerar os diferentes componentes do fato social total-jurídicos, econômicos, estéticos, religiosos etc. além dos distintos momentos da vida individual e de formas de expressão - conclui:

Tudo isso é claramente social, num certo sentido, uma vez que é somente na forma de fato social que esses elementos de natureza tão diversa podem adquirir uma significação global e tornarem-se uma totalidade. Mas o inverso é igualmente verdadeiro: pois a única garantia que podemos ter de que um fato total corresponde à realidade, em vez de ser acúmulo arbitrário de detal hes mais ou menos verídicos, é que ele seja apreensível numa experiência concreta (...) (Lévi-Strauss, 1971: 24).

No caso específico da cidade, a discussão começou com a pergunta: qual a unidade de análise, a cidade em seu conjunto ou cada prática cultural em particular? A proposta era considerar os atores sociais e suas práticas não como elementos isolados, dispersos e submetidos a uma inevitável massificação, mas em suas táticas (De Certeau, 1994), seus "arranjos", ou seja - e fazendo um paralelo com o termo empregado mais acima, suas experiências concretas - nas esferas do trabalho, religiosidade, lazer, cultura, política, vida associativa, estratégias de sobrevivência: devidamente descritos em seus aspectos estruturantes, deixam antever regularidades e formas recorrentes.

\subsection{UMA APLICAÇÃO CONCRETA: O CIRCUITO SATERÉ-MAWÉ}

Essas categorias já foram extensamente descritas em trabalhos anteriores e aplicadas a diferentes recortes etnográficos ${ }^{13}$; opto, porém, por deter-me um pouco mais sobre circuito e sua aplicação num campo novo para o Núcleo de Antropologia Urbana, provocativamente denominado, por meus alunos, de "etnologia urbana", não só por abrir um recorte pouco estudado - cidades da Amazônia com significativa presença indígena -, mas por tentar uma interlocução com a área tradicional da Antropologia dedicada ao estudo dessas populações. ${ }^{14}$

É uma boa ocasião para novas elaborações, a exemplo do que ocorreu com a categoria pedaço, resultado da incorporação de uma noção nativa no interior de um modelo já existente - a conhecida oposição casa versus rua de Da Matta: daí resultou um novo significado, com produtivas aplicações para além do contexto inicial de sua, digamos, descoberta: da periferia ao centro. Trata-se, agora, de uma nova negociação: a noção de circuito desenvolvida em pesquisas no contexto da cidade de São Paulo, às experiências urbanas dos Sateré-Mawé e algumas formulações apresentadas por Tim Ingold - $d$ welling, wayfaring (2000) e lines (2007). ${ }^{15}$ Assim, ao tentar aplicar a categoria do circuito para descrever a particular forma de inserção dos Sateré inicialmente em Manaus, foi preciso proceder que há diferentes modos de ser das coisas, ou se ele/a está apenas sendo vago/a e impreciso/a, e neste caso trata-se de um fracasso descritivo. Isso é uma coisa que me irrita a mais não poder. Depois, a fluidez e a ambiguidade deram lugar à noção de fragmentação - outra coisa que não tolero. Quando as pessoas dizem que o mundo é fragmentado, todo esse jargão atual sobre... vocês sabem, aquele tipo de coisa de que [James] Clifford gosta. Isso me irrita porque aqueles que usam a noção de fragmentação supõem uma noção de inteireza ou totalidade que permanece não analisada. Isso tudo é meramente uma forma de evitar ter que fazer as conexões" (1999: 167-168).

13 Econtinuam sendo, em pesquisas das teses e dissertações de orientandos, em andamento: skatistas, hortas urbanas, futebol de várzea, boxe, ciclistas, índios em contextos urbanos.

14 Ainda que pouco estudados, se comparados com os temas clássicos da etnologia indígena, cabe mencionar alguns autores, entre outros, que trabalharam diferentes aspectos dessa dimensão, seja cidades de índios, presença indígena em cidades, seus direitos, processos migratórios etc.: Romano (1982); Lasmar (2005); Andrello (2006); Bernal (2009); Smiljanic, Pimenta e Baines (2009); Teixeira, Mainbourg e Brasil (2009); Nunes (2010); Rosado e Fagundes (2013); Comissão Pro-Índio de São Paulo (2013).

15 Algumas das observações que seguem tiveram uma primeira formulação no artigo publicado na revista Ponto Urbe "O circuito: proposta de delimitação da categoria" (Magnani, 2014). 
a alguns ajustes que permitiram não apenas seu uso em novos contextos, desde suas aldeias até os bairros da capital do estado, mas levaram à descoberta de novas potencialidades da categoria. ${ }^{16}$

Cabe ressaltar que, tal como pedaço, mancha, trajeto e pórtico, circuito é também um termo de uso comum - precisa ser trabal hado para ultrapassar esse plano. Assim, o circuito dos cinemas, tal como aparece nos cadernos de cultura dos jornais, consiste na enumeração das salas de projeção espalhadas pela cidade, com endereço, título do filme, horário e um pequeno comentário. $\mathrm{O}$ mesmo se aplica, por exemplo, ao circuito dos museus, de pontos turísticos etc. Mesmo convencional, esse significado não é para ser descartado, pois permite uma primeira identificação de tais pontos e sua localização: no caso dos Sateré-Mawé, numa aproximação preliminar, seu circuito assim pôde ser descrito: as aldeias Yapyrehyt e Waikiru no bairro Redenção em Manaus; a aldeia Hywy, às margens do igarapé Tarumã-açu, ainda no município de Manaus; a barraca de artesanato na praça Tenreiro Aranha, centro da cidade; a sede da Amism (Associação das Mulheres Sateré-Mawé), no bairro Compensa; a comunidade Sahú-Apé no município Iranduba, próximo a Manaus. Eà medida que a pesquisa prosseguia, novos pontos eram acrescentados, ampliando o registro da presença sateré na região do baixo Amazonas: a Casa de Trânsito em Parintins, a Casa do Estudante na cidade de Barreirinha e a própria sede da prefeitura desse município, uma vez que o prefeito é sateré; os templos da Igreja Adventista do $7^{\circ} \mathrm{Dia}$ por eles frequentados, as aldeias de Andirá-Marau na Terra Indígena, os pontos de embarque nos rios e igarapés, os de coleta de sementes, os cursos de Licenciatura Intercultural.

Mas o circuito dos Sateré-Mawé não se resume a uma lista, por mais completa que seja: eles nos ensinaram que na verdade seu circuito era o resultado da contínua movimentação por um território muito mais amplo que o circunscrito pelos habituais recortes dicotômicos, demarcados entre cidade/floresta, cidade/aldeia, terra firme/rio. Essa contínua (mas não aleatória) deambulação levantou a necessidade de incorporar a variável tempo na definição do circuito, até então muito calcado na dimensão espacial: são os trajetos, com sua temporalidade própria que circunscrevem o alcance e delimitam a duração de diferentes sub-circuitos, no âmbito de um circuito mais abrangente - no caso, o circuito sateré-mawé: vivo, dinâmico, justamente por toda essa movimentação. Assim, os trajetos das mulheres artesãs pela cidade constituem o circuito específico da coleta de sementes, como mostrou Ana Sertã (2015); a frequência aos cursos de Licenciatura Intercultural, enquanto duram, conforma outro circuito, o dos "acadêmicos", como se auto intitulam os alunos desses cursos, segundo os relatos de Ana Fiori (s/d); o calendário de retiros espirituais e cultos instaura o circuito religioso, como evidencia a pesquisa de Marielli Mazzochi (s/d) sobre a presença
16 Os Sateré-Mawé habitam tradicionalmente uma região situada na jurisdição de cinco municípios, entre os estados do Amazonas e Pará: Barreirinha, Parintins, Maués, Itaituba e Aveiro, homologada como Terra Indígena em 1986. Sua população atual é de 9.400 pessoas e, segundo as divisões censitárias habituais, 7.502 vivem em áreas indígenas e 1.598 em áreas urbanas, sendo que 600 na cidade de Manaus. Sua língua integra o tronco linguístico Tupi e se consideram os "filhos do guaraná" (Paullinia cupana, da família das Sapindáceas), planta que é nativa de seu território e foi por eles domesticada. O contato com este povo remonta ao século XVII, mas é a partir da década de 1970 que sua presença se faz notar mais claramente nas cidades da região e na capital do estado. 
da Igreja Adventista entre os Sateré; a realização da Tucandeira, em Manaus, em Iranduba e nas aldeias mostra diferentes alcances do circuito desse ritual; as visitas e permanências em casa de parentes, por todo o território, segundo José Agnello (s/d), permitem identificar o circuito do parentesco e da residência; a participação na liga de futebol amador de Manaus, o "Peladão", que envolve peregrinação do(a)s atletas com as respectivas torcidas por campos de futebol, revela seu circuito futebolístico, a julgar pelo estudo de Rodrigo Chiquetto (2014). Toda essa movimentação envolve, em grande medida, barcos recreio, cataias, lanchas e rabetas pelos rios, paranás e igarapés que cortam todo o circuito, como descreveu Yuri Tambucci (2014). ${ }^{17}$

Conforme a natureza da atividade à qual determinado circuito dá sustentação, e as particularidades dos atores que o percorrem, seu alcance pode ser ampliado ou restringido; ele pode incluir novos pontos, abandonar uns, valorizar outros. Assim, para conseguir sementes para a confecção de braceletes e colares, as artesãs em seus trajetos percorrem espaços da cidade (o mercado, terrenos baldios, quintais) e da floresta em determinados períodos; para realizar o ritual da Tucandeira (que implica buscar as formigas, trançar as luvas, encontrar um bom cantador, identificar e convidar possíveis "ferrantes"), ${ }^{18}$ os trajetos e sua temporalidade serão outros. Os circuitos assim formados podem se sobrepor, se encontrar, servir a múltiplos usos; podem ser substituídos, pois, ainda que tenham como referência determinados espaços na paisagem, não são estáticos, fixos. Trajetos atualizam, acionam e dinamizam os circuitos; circuitos dão visibilidade e sustentação aos trajetos.

A experiência urbana dos Sateré-Mawé, em vez de confinada a determinados espaços numa cidade pronta (e, em alguns aspectos, hostil), plotada em alguma representação cartográfica fixa, conforma complexos circuitos por onde transitam humanos e não humanos, parentes da cidade e das terras indígenas, lideranças e políticos, estudantes e professores. Está-se muito distante da visão de pobres índios confinados na periferia de uma grande cidade: eles têm agência, deixam suas marcas, transitam por extensas redes de socialidade com contornos próprios e que dialogam com as dos Tukano, dos Tikuna, dos Kambeba, dos Mura, dos Munduruku - isso para pensar numa Manaus indígena; mas também com a cidade dos demais moradores que têm seus trajetos em outros circuitos formados pelo universo do trabalho, pelas instituições de saúde, de ensino, cultura, lazer etc. Vistas separadamente, essas formas de inserção podem parecer irrelevantes; entretanto, se vistas na chave em que Lévi-Strauss as classificava de "infinitesimais", articuladas como partes de alguma totalidade, são lidas como unidades de sentido e incorporadas como princípios de inteligibilidade. Dizem algo sobre os Sateré, sobre suas táticas, sobre os traços que deixam numa paisagem mais ampla-que inclui certamente a cidade, mas não se restringe a ela.
17 Ana Luísa Sertã defendeu sua dissertação em 2016, Rodrigo Chiquetto e Yuri Tambucci em 2014; os demais estão em processo de elaboração de suas teses - Ana Fiori e José Agnello-ou dissertação-Marielli Mazzochi. Todos fazem parte do GEU-Crupo de Etnologia Urbana - que se formou a partir da participação de alguns membros do NAU no projeto "Paisagens ameríndias: habilidades, mobilidade e socialidade nos rios e cidades da Amazônia", entre 2008 e 2012, a convite dos professores Marta Amoroso e Márcio Silva. Este projeto foi desenvolvido no âmbito do Procad, Programa Nacional de Cooperação Acadêmica, que prevê intercâmbio entre um programa de pós-graduação consolidado e outro, de implantação mais recente: neste caso entre o PPGAS da USP e da UFAM. O eixo da pesquisa que coube inicialmente ao NAU foi "Tempo livre e lazer nas cidades amazônicas com ênfase nas populações indígenas". O objetivo era fazer uma etnografia de formas de lazer e modalidades de uso do tempo livre nos espaços de socialidade da população indígena nas cidades da Amazônia como modo de abordagem inovadora de um dos processos de incorporação da vida urbana pelas populações nativas. No decorrer do trabalho tal objetivo foi ampliado, ensejando os recortes contemplados pelos trabalhos dos alunos acima citados.

18 Trata-se de um ritual de passagem masculino em que meninos e jovens devem enfiar as mãos em luvas de palha trançada, repletas de formigas, após o que são considerados "verdadeiros guerreiros”. É um ritual complexo e trabalhoso, que aciona uma extensa rede de relações, pois é preciso convidar candidatos dispostos a serem "ferroados"; contatar um bom mestre de cerimônia, geralmente da terra indígena, para conduzir os cantos e danças; buscar, retirar e tratar as formigas a serem inseridas nas luvas; estas, depois de tecidas, devem ser 


\section{CONCLUSÃo}

É o momento de voltar ao início deste texto, com a pergunta que introduziu o desafio:

“(...) pode a Antropologia, com os conceitos e métodos de análise forjados ao longo de pesquisas em sociedades de pequena escala - cuja forma de assentamento não era, precisamente, a cidade -lidar com a complexidade dos atuais aglomerados urbanos, em toda sua diversidade? Em segundo lugar-e esse é, propriamente, o desafio de fundo - não seria justamente tal legado o que dá a seu olhar, de perto e de dentro, determinada acuidade, lá onde uma visão de fora e de longe passaria ao largo?

Com efeito, ainda que a cidade não tenha sido um objeto de estudo particularmente privilegiado na tradição antropológica clássica, aqui e ali ela aparece e às vezes de forma surpreendente, como foi visto nas passagens coligidas em Tristes Trópicos. Neste caso, chamou a atenção o fato de Lévi-Strauss, apesar de enfatizar o lado "infinitesimal" como constitutivo da dinâmica urbana, ter trazido a imagem das ruínas de cinco mil anos de Mohenjo-Daro, na Índia, como uma espécie de antecipação da forma em retícula que encontrou em cidades do Norte do Paraná, na década de 1930: uma espécie uma permanência de longa duração; uma estrutura, em suma.

Com todas as ressalvas, incluindo as do próprio autor, havia aí uma pista interessante: não ter de optar por uma ou outra direção. Se num primeiro momento estabeleci uma oposição entre o olhar "de perto e dentro" e o "de fora e longe" (e fiz uma escolha pela primeira opção), foi para enfatizar a importância de apreciar e registrar os múltiplos, surpreendentes e criativos arranjos dos atores sociais em meio à suposta determinação das variáveis macro estruturais-econômicas, demográficas, ambientais. ${ }^{19}$ Contudo, na continuação, ambas as perspectivas se complementam: a contínua passagem entre elas permite caminhar em busca de regularidades, escapando seja da fragmentação tão ressaltada em determinadas análises da vida urbana contemporânea, seja da fácil solução de refugiar-se em generalidades. Em outros termos: de uma antropologia na cidade, voltada para o registro e análise das mais variadas práticas dos atores sociais nos campos do trabalho, locomoção, usos (e contrausos) do espaço, formas de religiosidade, lazer, participação política etc., em direção a uma antropologia da cidade, interessada na identificação de permanências mais abrangentes e duradouras que transcendem as escolhas, táticas e arranjos individuais. ${ }^{20}$

As análises convencionais escolhem um determinado aspecto - o anonimato, a exclusão, a multidão - e o erigem como chave explicativa, rígida: a perspec- adornadas com penas de gavião real e arara vermelha, materiais de difícil obtenção. É preciso ainda obter as polpas de jenipapo para o preparo da tintura para os grafismos corporais, organizar o espaço na comunidade para a realização do ritual e receber visitantes - parentes, vizinhos, pesquisadores, imprensa-o que inclui levantar barracas para venda de artesanato, comidas e bebidas típicas, montar o palco para apresentações musicais e até alvos para disputas de arco e flecha. Enfim, supõe uma série de atividades que demandam tempo, dinheiro, uma rede de relações e conhecimentos específicos.

19 Cabe lembrar que a própria Saskia Sassen, conhecida por sua obra The Global City (1991), já citada, em recente passagem por São Paulo por ocasião do Seminário "Cidades e Territórios", em junho de 2016, reconheceu "estar mais interessada em estudar espaços que conseguem transformar seus habitantes em sujeitos urbanos (...) espaço urbano é uma habilidade, nem que seja apenas por algumas horas" (entrevista para a Folha de São Paulo, 14 de junho de 2016).

20 Diferentemente do que propusera Geertz, para quem os antropólogos "não estudam as aldeias (tribos, cidades, vizinhanças...) eles estudam nas aldeias" (1978: 32). 
tiva etnográfica, de perto e de dentro, contudo, ao escutar o outro, permite deter-se nas passagens entre os distintos planos, nas negociações e conflitos em torno de usos do espaço público. Em certa medida, é válido até recuperar determinadas características da vida urbana que se tornaram canônicas, como a famosa atitude blasé de Simmel; não, porém como sua marca constitutiva e exclusiva, e sim como uma das possibilidades: pode-se alternar entre um deambular protegido pelo anonimato ou recolher-se nos pertencimentos propiciados pelo seu pedaço. E em determinada circunstâncias, porém, os trajetos arrancam os atores sociais de seus pedaços habituais e os colocam em manchas mais amplas - marchas, manifestações, ocupações - ou dão visibilidade a circuitos estendidos.

Os cinéfilos, por exemplo, que no seu cotidiano percorrem discretamente o circuito específico dos filmes cult, formado por determinadas salas espalhadas pela cidade, em algumas ocasiões assumem visibilidade e agência próprias: foi o caso da recente mobilização em defesa de uma sala em São Paulo, o Cine Belas Artes, ameaçada de despejo pelo proprietário, que queria dar outra destinação ao prédio. ${ }^{21}$ Foram acionados a Câmara dos Vereadores, o Ministério Público, os órgãos de defesa do patrimônio, a imprensa, as redes sociais. Resultado: o Belas Artes, após dois anos de mobilização em sua defesa, em 2012 foi tombado e reaberto, com a nova categoria de patrimônio imaterial, pelo papel que cumpre no circuito. ${ }^{22}$ Mas, por ocasião da Mostra Internacional de Cinema, a presença dos cinéfilos é de outra ordem: fazem questão de exibir-se nas intermináveis filas, dão depoimentos sobre suas preferências, comparecem a eventos com cineastas estrangeiros, descrevem seus trajetos e as estratégias para não perder nenhuma projeção, e assim por diante.

Este é um exemplo, entre tantos, de uma dinâmica que, como foi visto no caso dos Sateré-Mawé, transcende os limites e contornos físicos-sejam da metrópole, das áreas conurbadas, do condomínio, do bairro, da vila, da aldeia. Nesse sentido, a cidade - não mais como uma unidade circunscrita-deixa de ser o ponto de partida para a análise, para ser, no limite, o de chegada, como uma determinada modalidade de assentamento humano e de agenciamento de relações, com uma forma estrutural especifica. As sobreposições, os links e passagens entre os recortes identificados pelas unidades de análise compõem a malha, a trama urbana, as lines e o meshwork, para usar os termos de Tim Ingold (2007). Assim, com a descrição desses arranjos - recortes/totalidades experimentadas pelos atores e reconhecidas pelo registro etnográfico-pode-se avançar em direção a uma visão mais geral do fenômeno urbano sem ficar preso aos limites físicos da cidade: em suma, com base em antropologia na cidade, não perder o horizonte de uma antropologia da cidade.
21 Esta sala está situada numa conhecida mancha de lazer pesquisada pelo NAU e seus resultados foram publicados em Magnani e Torres (1996). Com diferentes denominações-Cine Ritz, Trianon, Belas Artes e, atualmente Cine Caixa Belas Artes, em virtude de seu novo patrocinador-existe desde 1943, em frente ao tradicional Café Riviera, o que atesta uma das características das manchas, sua maior permanência na paisagem urbana. 
José Guilherme Cantor Magnani é Professor Titular do Departamento de Antropologia da FFLCH da USP. É mestre em Sociologia pela Facultad Latinoamericana de Ciencias Sociales (Flacso/Chile), doutorou-se em Ciências Humanas (Antropologia Social) pela Universidade de São Paulo em 1982, defendeu tese de Livre-Docência em 2010 e de Titular em 2012 na mesma universidade. É coordenador do Laboratório do Núcleo de Antropologia Urbana da usP.

\section{REFERÊNCIAS BIBLIOGRÁFICAS}

ANDRADE, José Agnello

s/d Saterização da cidade: identidade, multi-localidade e cultura entre aldeias e cidades habitadas pelos Sateré-Mawé na Amazônia. São Paulo, tese, Universidade de São Paulo, em andamento desde 2013.

\section{ANDRELLO, Ceraldo}

2006 Cidade do índio: transformações e cotidiano em lauaratê. São Paulo, Editora Unesp.

AUGÉ, Marc

1994 Não lugares: introdução a uma antropologia da supermodernidade. Campinas, Papirus.

BENÉVOLO, Leonardo

1983 [1975] História da cidade. São Paulo, Perspectiva.

BERMAN, Marshal

1989 Tudo que é sólido desmancha no ar. São Paulo, Companhia das Letras.

BERNAL, Roberto Jaramillo

2009 Índios urbanos: processo de reconformação das identidades étnicas indigenas em Manaus. Manaus, EDUA.

BORJA, Jordi

1995 “La Ciudad Mundial". In MEYER, Regina e GROSTEIN, Marta (orgs.), Memória do Encontro Centro XXI-Anais. São Paulo, Associação Viva o Centro.

BRAUDEL, Fernand

1995 [1949] OMediterrâneo e o Mundo Mediterrânico na época de Felipe II. Lisboa, Publicações Dom Quixote. 
CANDIDO, Antonio

1964 Os parceiros do Rio Bonito: estudo sobre o caipira paulista e as transformações dos seus meios de vida. Rio de Janeiro: José Olympio.

CHIQUETTO, Rodrigo

2014 A cidade do futebol: etnografia sobre a prática futebolística na metrópole manauara. São Paulo, dissertação, Universidade de São Paulo.

CLIFFORD, James

1998 "Sobre a autoridade etnográfica". In . A experiência etnográfica: antropologia e literatura no século xx. Rio de Janeiro, Editora UFR].

COMISSÃO PRÓ-ÍNDIO

2013 A cidade como local de afirmação dos direitos indígenas. São Paulo, Comissão Pró-Índio de São Paulo.

DE CERTEAU, Michel

1994 A invenção do cotidiano: artes de fazer. Petrópolis, Vozes.

DURKHEIM, Émile

1973 De La División del trabajo social. Buenos Aires, Shapire Ed.

EVANS-PRICHARD, Edward

1978 Os Nuer. São Paulo, Perspectiva.

GEERTZ, Clifford

1978 A interpretação das culturas. Rio de Janeiro, Zahar.

FIORI, Ana Letícia

s/d Comose formam índios acadêmicos? Um estudo sobre trânsitos de cotidianose saberes entre os discentes dos Cursos de Pedagogia Intercultural da Universidade Estadual do Amazonas. São Paulo, tese, Universidade de São Paulo, em andamento desde 2013.

FRÚCOLI, Heitor

2000 Centralidade em São Paulo. São Paulo, Edusp.

FUSTEL DE COULANGES

1941 [1864] A cidade antiga. Lisboa, Editora Clássica, 2 vol. 
HABERMAS, Jürgen

1992 [1981] "Arquitetura moderna e pós-moderna". In ARANTES, Otília e ARANTES, Paulo E. (orgs.), Um ponto cego no projeto moderno de Jurgen Habermas. São Paulo, Brasiliense.

HANNERZ, UIf

1986 Exploración de la ciudad: hacia una antropologia urbana. Mexico, Fondo de Cultura Económica.

HARVEY, David

1993 [1989] Condição pós-moderna. São Paulo, Loyola.

HERMANN, Lucila

1948 Evolução da estrutura social de Guaratinguetá num período de trezentos anos. São Paulo, Instituto de Administração, Faculdade de Ciências Econômicas.

INGOLD, Tim

2000 The Perception of the Environment. Essays on Lifehood, Dwelling and Skill. Londres e Nova York, Routledge.

2007 Lines: A BriefHistory. Londres, Routledge.

JACOBS, Jane

1992 [1961] The Death and Life of Great American Cities. Nova York, Vintage Books, Random House Inc.

LASMAR, Cristiane

2005 De volta ao lago de Leite: gênero e transformação no Alto Rio Negro. São Paulo, Editora Unesp.

LEACH, Edmund

1989 A diversidade da antropologia. Lisboa, Edições 70.

LE CORBUSIER

1989 [1941] A carta de Atenas. São Paulo, Hucitec/Edusp.

LEROI-GOURHAN, André

1987 [1964 e 1965] O gesto e a palavra. 2 vol. Lisboa, Edições 70.

LÉVI-STRAUSS, Claude

1962 "A crise moderna da Antropologia". Revista de Antropologia, vol. 10, n. 1-2. 
1971 "Introducción a la obra de Marcel Mauss". In MAUSS, Marcel. Sociologia y antropologia. Madrid, Editorial Tecnos.

1976 O pensamento selvagem. São Paulo, Companhia Editora Nacional

1996 Tristes Trópicos. São Paulo, Companhia das Letras.

LÉVI-STRAUSS, Claude e ERIBON, Didier

1990 De perto e de longe. Rio de Janeiro, Nova Fronteira.

MACNANI, José Guilherme C.

1999 "As cidades de Tristes Trópicos". Revista de Antropologia. São Paulo, FFLCH/ USP, vol. 42, n. 1/2: 97-112.

2002 "De perto e de dentro: notas para uma etnografia urbana". Revista Brasileira de Ciências Sociais". São Paulo, ANPOCS, vol. 17, n. 49: 11-30.

2012 Da periferia ao centro: trajetórias de pesquisa em Antropologia Urbana. São Paulo, Ed. Terceiro Nome.

2013 "Anthropology between heritage and musems". Vibrant - Virtual Brazilian Anthropology, vol. 10, série 1.

2014 "O circuito: proposta de delimitação da categoria". Ponto Urbe, n.15.

MAGNANI, José Guilherme C. e TORRES, Lilian

1996 Na metrópole: textos de Antropologia Urbana. São Paulo, Edusp/Fapesp.

\section{MARCUS, George}

1991 "Identidades passadas, presentes e emergentes: requisitos para etnografias sobre a modernidade no final do século xx a nível mundial". Revista de Antropologia, São Paulo, FFLCH/USP, vol. 34 .

MAYER, Harold e KOHNE, Clyde

1967 [1959] Readings in Urban Geography. Chicago, University of Chicago Press.

MAZZOCHI, Marielli

s/d Circuitos de fé: Sateré-Mawé, cidades e cristianismo. São Paulo, dissertação, Universidade de São Paulo, em andamento desde 2014.

MELLOR, J.R.

1984 Sociologia urbana. Porto, Rés. 
MONGIN, Olivier

2009 [2005] A condição urbana: a cidade na era da globalização. São Paulo, Estação Liberdade.

MUMFORD, Lewis

1965 [1961] A cidade na história. 2 Vol. Belo Horizonte, Itatiaia.

NOGUEIRA, Oracy

1962 Família e comunidade: um estudo sociológico de Itapetininga, São Paulo. Rio de Janeiro, Centro Brasileiro de Pesquisas Educacionais/InEP/MEC.

NORA, Pierre

1984 Les Lieux de mémoire. Paris, Editions Callimard.

NUNES, Eduardo

2010 "Aldeias urbanas ou cidades indígenas? Reflexões sobre índios e cidades". Espaço Ameríndio, Porto Alegre, vol. 4, n. 1: 9-30.

PIERSON, Donald

1951 Cruz das Almas, a Brazilian Village. Washington, Smithsonian Institute, publication n. 12

ROMANO, Jorge

1982 "Indios proletarios en Manaos: el caso de los Satere-Mawé citadinos". Brasília, tese, unB.

ROSADO, Rosa Maris e FACUNDES, Luiz F. Caldas (orgs.)

2013 Presença indígena na cidade: reflexões, ações e políticas. Porto Alegre, Núcleo de Políticas Públicas para Povos Indígenas.

SAHLINS, Marshall

1997 “O 'pessimismo sentimental' e a experiência etnográfica: porque a cultura não é um 'objeto’ em via de extinção”. Mana, 3 (1 e 2).

SASSEN, Saskia

1991 The Clobal City: New York, London, Tokyo. Princeton, Princeton University Press.

SCHOENAUER, Norbert

1984 [1981] 6.000 Años de Hábitat. Barcelona, Editorial Gustavo Gili. 
SERTÃ, Ana Luísa

2015 Seguindo sementes: um estudo sobre circuitos e trajetos Sateré-Mawé na Amazônia. São Paulo, dissertação, Universidade de São Paulo.

SICA, Paolo

1977 [1970] La imágen de la ciudad. Barcelona, Editorial Gustavo Gili.

\section{SIMMEL, Georg}

1987 "A metrópole e a vida mental". In VeLho, Otávio Guilherme (org.), O Fenômeno Urbano. Rio de Janeiro, Guanabara.

SMILJANIC, M. Inês; PIMENTA, José e BAINES, Stephen Grant (orgs.) 2009 Faces da indianidade. Curitiba, Nexo Design.

STRATHERN, Marilyn

1999 "Entrevista: no limite de uma certa linguagem". Mana, vol.5, n. 2.

2014 Oefeito etnográfico. São Paulo, Cosac Naify.

TAMBUCCI, Yuri

2014 Rio a fora, cidade a dentro: transporte fluvial e modos de viver no Amazonas. São Paulo, dissertação, Universidade de São Paulo.

TEIXEIRA, Pery; MAINBOURG, $M$. Therèse e BRASIL, Marília

2009 "Migração do povo indígena Sateré-Mawé em dois contextos urbanos distintos na Amazônia". Caderno CRH, vol. 22, n. 57: 1-16.

TÖNNIES, Ferdinand

1963 Community and society. Nova York, Harper and Row.

VIVEIROS DE CASTRO, Eduardo e VELHO, Gilberto

1978 "O conceito de cultura e o estudo de sociedades complexas: uma perspectiva antropológica". Artefato, Jornal de Cultura, ano I, n.1.

WAGLEY, Charles

1953 Amazon Town: A Study of Man in the Tropics. Nova York, Macmillan.

WEBER, Max

1999 Economia e sociedade. Brasília, Editora da unB. 
WILLEMS, Emílio

1947 Cunha: tradição e transição em uma cultura rural do Brasil. São Paulo, Secretaria da Agricultura.

WILLEMS, Emílio e MUSSOLINI, Gioconda

1952 Buzios Island: A Caiçara Community in Southern Brazil. Nova York: ]. ]. Augustin Publisher.

\section{Urban Anthropology: Challenges and Perspectives}

\section{ABSTRACT}

This article proposes two initial questions: Can the Anthropology, with its concepts and methods forged through researches in small-scale societies, deal with the heterogeneity of contemporary urban clusters, in all their diversity and extensions? Secondly, it is not this very legacy that provides the from close up and within approach with a certain accuracy that would be lost in a far away and external perspective? This article reviews different approaches to the city as constituted as a research subject; followed by tha Anthropological account of the city; to ultimately introduce the main topic of the article: the conditions to ethnographical practice, Anthropology's particular method, in contemporary urban contexts.

Recebido em agosto de 2016. Aceito em agosto de 2016

\section{KEYWORDS}

Urban Anthropology, Ethnography, Methodology, Contemporary Cities, Sateré-Mawé Circuits in Amazon 